SHS Web of Conferences 2, 00029 (2012)

DOI: $10.1051 /$ shsconf $/ 20120200029$

(C) Owned by the authors, published by EDP Sciences, 2012

\title{
Psychosocial changes in the image of women engaged in prostitution
}

\author{
M. Smirnova \\ Riga Stradiņš University, Latvia
}

\begin{abstract}
This paper is aimed to show how engaging in sexual services affect psychosocial image of women. Investigating causes of women engagement in prostitution and the point of the problems women face daily life, it is possible to see psychosocial aspects changes when women take decision to offer sexual services. The author of the paper comes to the conclusion that for women who provide sexual services must be developed social services.
\end{abstract}

Key words: prostitution, psychosocial changes

Women engaged in prostitution in society occupy a marginalized position. Women engaged in prostitution face social, economic and psychological difficulties. Analyzing women falling into prostitution, it is evident that the causes of female arrival at a sex business is a negative social environment, lack of education, different addictions, experience of violence, etc. The capacity of women engaged in prostitution to cope with various difficulties, such as, material problems, addictions, the ability to deal with violence against them etc. is different-from not developed capacity to solve their own problems to a level where the women learned emotionally and psychically function and survive in a new environment.

\section{Materials and methods}

The study was carried out in Riga where were made 10 semi-structured interviews with women who are engaged in prostitution and was analyzed research made in Vancouver (Canada) where were interviewed 100 women who are engaged in prostitution.

\section{Phases of women engaging in prostitution}

Frequently, women who choose to enter prostitution decision are based on the purpose of financial boundaries. Woman is able to obtain material benefits for themselves and their families. Women realize their wishes and needs what could be satisfied by earned money in prostitution. At this stage women rationalizing her values, morals conflicting issues, to engage prostitution for money.

In women's opinion the financial benefit for her family and material security is seen as survival strategy. Under age persons arguments entering prostitution are such as difficulties to find a work at this age and other reasons. Women who came from disadvantaged families see prostitution as a way to improve her financial situation. Offering sexual services women adopt this new way of life who have new rules in order to survive in this environment, as well as explore new values and skills to integrate into that environment.

Dealing with prostitution women face with daily challenges - police raids, developing relationships with her clients, relationships with pimps, violence, concealing their activities from others (such as shame), dangerous client assessment, etc.

This is an Open Access article distributed under the terms of the Creative Commons Attribution License 2.0, which permits unrestricted use, distribution, and reproduction in any medium, provided the original work is properly cited. 


\section{SHS Web of Conferences}

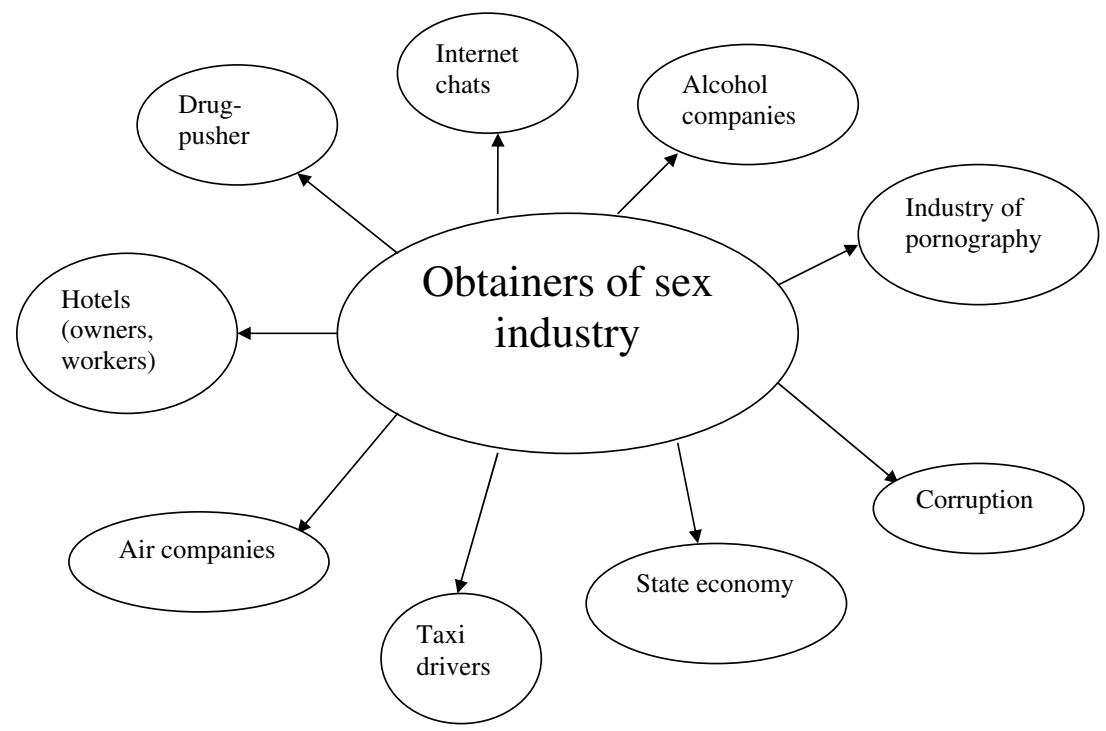

Figure 1. The industrialization and globalization of sex.

Woman engaged in prostitution distance themselves from the communication with the various traditional institutions - religious, political and social institutions. In this environment women find friends and acquaintances with similar values and behaviour. It is an environment where women engaged in prostitution does not condemn because other women have the same values and occupation.

Skills and knowledge helps to socialize women in the environment of prostitution (Williamson, Folaron, 2003). Acquired new skills helps woman engaged in the prostitution to survive in this environment and at the same time those women are bounded by a majority of their accepted values, norms, behaviour and actions.

\section{The globalization of sex industry}

Prostitution is a phenomenon where are involved various persons (pimps, criminal groups, those who offer sexual services, etc.) and institutions (see Figure 1).

Sex accessory shops, medical services, pharmacies, security, transport, housing landlords, etc. also benefit from sex industry.

The rewards of sex industry can be disribed as direct (pimps, taxi drivers, who pay the customer to be delivered to the sex service providers, Internet pornography industry chat, drug dealers, etc.) and indirect (the state's economy, which is obtained with the increased influx of tourism, airlines, whose services are used by sex tourists, hotels which takes up a prostitute service users, etc.).

\section{The changes of psychosocial image}

Any experience influence and make the view of human world, the ability to solve problems, ability to take different decisions. Problems, values and skills affect women engaged in prostitution psychosocial image.

Research made in Vancouver (Canada) where were interviewed 100 women engaged in prostitution was found that those women face with violence and post-traumatic stress disorder (PTSD). 82\% of the interviewees replied that in the past they have experienced sexual abuse, $72 \%$ experienced physical violence, $90 \%$ was violently engaged in prostitution, and $78 \%$ had been raped. Providing sexual services, 
Int. Conf. SOCIETY. HEALTH. WELFARE; Congr. of Rehabilitation Doctors of Latvia

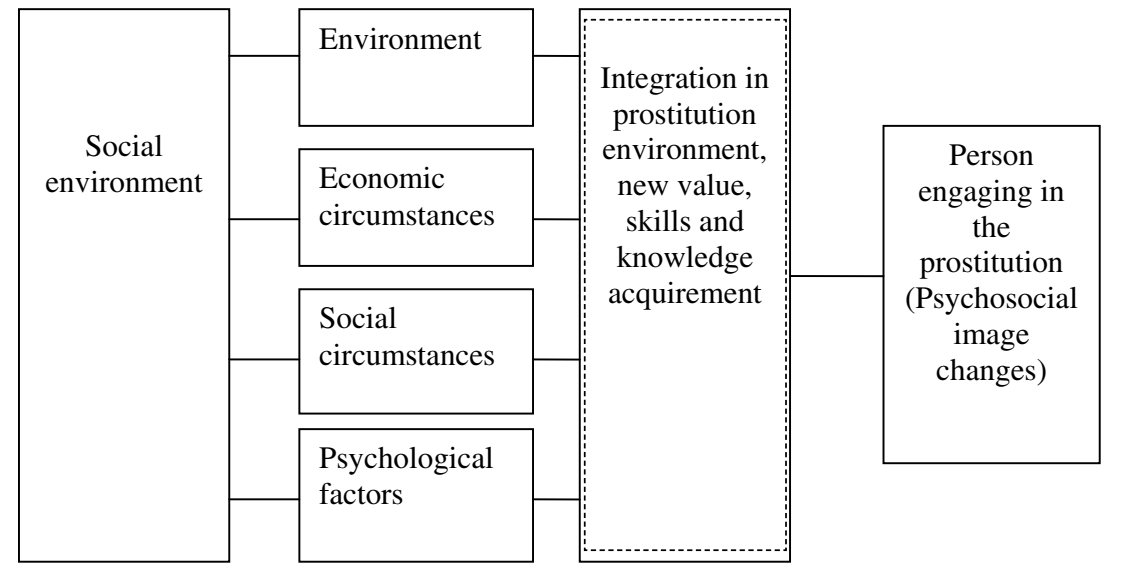

Figure 2. Circumstances which facilitate women engagement in the prostitution.

women learn skills to defend her; she develops an action plan what she will do if some of customers will attack her.

Many of the interviewee mentioned the kicking and beatings, shock and broken bones (broken jaw, arm, neck bones, fingers, etc.), as well as cuts, blue eyes and "thick" lips. Customers and pimps regularly exposed women to violence when they refused to comply with customers' desires for specific sex.

$86 \%$ of respondents replied that at the present or past they have faced homelessness. $82 \%$ emphasized the need for treatment of drug or alcohol addiction. $88 \%$ of women admitted that they had been verbally insulted. One respondent commented that "many customers at the beginning are very polite. At the start of sexual intercourse clients become verbally violent".

The analysis of women engaged in prostitution faced with such problems as memory problems (66\%), difficulty in concentrating (66\%), headache (56\%), dizziness (44\%), vision problems (45\%), hearing problems (40\%), balance problems (41\%), myalgia (78\%), arthralgia (38\%) and limb edema (33\%). Cardiovascular symptoms include chest pain (43\%), pain/numbness of hands/feet (49\%), irregular heart rate $(33 \%)$ and shortness of breath $(60 \%)$. $24 \%$ have pain during menstruation, and pain in the vagina. $23 \%$ have chest pain. $30 \%$ have Hepatitis C.

PTSD is characterized by fear, depression, insomnia, irritability, memory flickers and emotional numbness (Farley, Lynne, Cotton, 2005; 242-244, 246, 250-251).

Women who worked in prostitution have the same number of traumatic brain damage (from beating and kicking to the head, strangulation or beating the head against objects such as the car bonnet) as victims of torture (Hīlija, Okonnora, 2006; 25).

\section{Results}

As a cause of engaging in the prostitution are mentioned such reasons as starting use drugs or alcohol addiction. Some of women were engaged in the prostitution by their friends. Women who engaged in prostitution are ashamed of their occupation, so they do not tell their relatives and friends about it.

Research made in Riga showed that women who engaged in prostitution are between the ages of 21 to 51. Women are faced with client violence (rape, beating and hand strangulation). Despite the fact that women avoid from pregnancy and different diseases they face with unwanted pregnancies so it has a high abortion rate. Interviewed women are not aware of the fact that if they want deal with prostitution in Latvian territory they need medical card. Women engaged in prostitution regularly use drugs, so the time they spend in providing sexual services is dependent on the material collected funds for the purchase of drugs. Among women there is also tendency to use alcohol. Women engaged in prostitution 


\section{SHS Web of Conferences}

are unable to integrate into the labor market. The low level of education or acquired loss of current education nowadays as well as poor knowledge of Latvian language hinder women's chances of finding a good paid job.

\section{Discussion}

The research results suggest that women engaged in prostitution need to have social services. Social service, which could offer for women in prostitution, must have an inclusive nature, which is provided by teamwork support. Such professionals as social worker (team leader), gynaecologist, psychologist, lawyer, etc. professionals in team work must be involved.

\section{Conclusions}

Studies in different countries show that women engaged in the prostitution face the social, economic and medical problems. Experienced violence, substance abuse, social problems, low social skills and a variety of medical and psychological problems make psychosocial changes in women personality.

Women in prostitution face with values change, new knowledge and skills. Abuse in past and other problems promotes the psychosocial change of image.

\section{References}

[1] Farley, M., Lynne, J., Cotton, A.J. (2005) Prostitution in Vancouver: Violence and the Colonization of First Nations Women.

[2] Hīlija, G., Okonnora, M. (2006) Informatīva rokasgrāmata: Prostitūcijas un cilvēku tirdzniecības saikne. Eiropas Sieviešu lobijs sadarbībā ar Resursu centru sievietēm. Marta.

[3] Williamson, C., Folaron, G. (2003) Understanding the Experiences of Street Level Prostitutes. Qualitative Social Work, vol. 2. 